IRSTI 06.51 .21

UDC 330.15

https://doi.org/10.46914/1562-2959-2020-1-4-250-257

Z.A. IMANGOZHINA, ${ }^{1}$

Master of economic sciences,

$\mathrm{PhD}$ student.

Financial Academy JSC ${ }^{1}$

\title{
THE HISTORY OF DEVELOPMENT AND FEATURES OF GAS INDUSTRY IN NORWAY AND THE NETHERLANDS
}

\begin{abstract}
Natural gas occupies one of the leading places in the energy system of the modern world. More and more countries are using environmentally friendly raw materials for domestic needs, moving away from coal consumption due to the decarbonization policy. The article provides an overview and analysis of data on two leaders in natural gas deposits in Europe: Norway and the Netherlands. Special attention is paid to the history of the development of the kingdoms gas market and its impact on the formation of this industry in the European Community and in the world. Both the largest deposits of Troll and Groningen and little-known small deposits discovered at the moment, such as Ekofix, Frigg, Drogen, Ozberg, OrmenLang, F4B, K5A, F4, FA and others, are considered. The development of oil and gas resources on the Norwegian Continental Shelf has followed different paths since the first commercial production of hydrocarbons began in 1971. All licensees on the Norwegian Continental Shelf are responsible for the sale of their own gas. In contrast, the Netherlands, which required very large investments for the development of the Groningen field, developed a new type of take or pay - "take or pay" contract, and the gas price was tied to the oil price to return a large amount of public investment. Some results on the development of the industry in the countries have been summed up.
\end{abstract}

Key words: European gas market, natural gas, gas exports, oil resources, investments, energy system, fields.

The study is addressed to the topic of the gas sector of two leading gas producing countries in Europe. These are Norway and the Kingdom of the Netherlands. These countries are the largest producers and exporters of natural gas in Europe.

Table 1 - Statistical survey of the world leaders in gas production in the world for 2017

\begin{tabular}{|l|c|c|l|l|}
\hline \multicolumn{1}{|c|}{ Country } & $\begin{array}{l}\text { Production volume } \\
\text { rating, billion } \mathrm{m} 2 .\end{array}$ & $\begin{array}{l}\text { Percentage of production } \\
\text { among leading countries }\end{array}$ & $\begin{array}{l}\text { The largest gas } \\
\text { fields }\end{array}$ & Geographic location \\
\hline USA & 762 & 29,82 & Gulf-Coast & Texas \\
\hline Russia & 649 & 25,40 & $\begin{array}{l}\text { Urengoiskoye, } \\
\text { Bovanenskoye }\end{array}$ & West and East Siberia \\
\hline Iran & 238 & 9,32 & SouthPars & Persian Gulf \\
\hline Canada & 184 & 7,20 & Rainbo-Lake & Newfoundland island \\
\hline Qatar & 163 & 6,38 & NorthPars & PersianGulf \\
\hline PRC & 143 & 5,60 & Dazhou & South-West China \\
\hline Norway & 127 & 4,97 & Troll-West & NorthSea \\
\hline Saudi Arabia & 115 & 4,50 & Ghawar & PersianGulf \\
\hline Algeria & 94 & 3,68 & Hassi-R Mel & NorthofAfrica \\
\hline Turkmenia & 80 & 3,13 & Galkynysh & South-EastofTurkmenia \\
\hline $\begin{array}{l}\text { Note - Compiled by the author, based on statistics: https://www.ceicdata.com/en/indicator/natural-gas- } \\
\text { consumption (reference date: } 20.10 .2019) .\end{array}$ \\
\hline
\end{tabular}

As can be seen, from table 1 below, Norway is in the top ten countries. At the current stage, the Kingdom of the Netherlands is not in this list, but back in 2013 and earlier this indicator was at around 85 billion cubic meters gas production per year [2].

In 2017, Norway reached a record level of gas production for its country, thereby standing on the 7 th line of the lead countries on gas production. According to the forecasts of the Norwegian Petroleum Administration (NPD), in this volume production will be stable until 2025 and then decrease to 90 
billion cubic meters in year. So the latest changes in forecast can show the more accurate result of assessment of the resource base, and also show the various ways of existing field developing. Under that the risk of incorrect forecasts until 2027 will be low. But after 2027, we see more political, economic and geological risks in forecasts especially because of the scarcity in positive gas field exploration. The development of oil and gas resources on the Norwegian Continental Shelf (NCS) has gone in different ways since the start of the first commercial production of hydrocarbons in 1971. In the early years of offshore operations, the development of gas resources was constrained by market and political considerations.

In May 1963 The Norwegian government proclaimed the sovereignty of the Norwegian Continental Shelf (NKS), according to this, all the natural resources of the NCS are owned by the state and only the government can issue exploration and production licenses.

In 1971, the Frigg gas field was discovered on the border between Norway and the United Kingdom. And already in 1972, the Norwegian government took a number of measures to regulate the oil and gas sector.

The Norwegian Petroleum Directorate is set up to manage the oil business and the state-owned company Statoil. The state share is $62 \%$. Statoil was assigned the right to have $50 \%$ of all future licenses. The maximum annual oil and natural gas production was also established.

Gas production began in 1977 at the Ecofisk and Frigg fields, but these fields are rapidly draining, so there were no long-term contracts with buyers from continental Europe and the UK. The search for new fields was also due to a government ban on offshore gas burning. Then that situation was solved by looking for European buyers with whom could be concluded a long-term contracts to build and finance a new export pipeline infrastructure. Difficulties in developing gas resources were finally overcome by the discovery and appraisal of the giant Troll field in 1979-83 and the conclusion of new gas sales agreements on the continent between 1986 and 1990 [1].

However, since January 1985, government participation in the oil and gas sector has undergone changes. Now the state's share varies depending on field.

Since the 70s, oil and gas have been produced at 106 fields. At the end of 2018, production was carried out at 83 fields, of which 63 in the North Sea, 18 in the Norwegian and 2 in the Barents Sea of gas in Norway: Troll Complex, Ecofix, Snorr, Drogen, Ozberg, Ormen Lange, Osgard, Kvitebjorn and Aasta Hansteen. At the end of 2019, it is planned to begin production at the new Johann Sverdrup field.

For the first 25 years, oil dominated the development of new fields and oil production at the oil and gas complex. However, since 2000, when oil production peaked, gas production increased dramatically [7].

The Troll produced its first gas in 1996 and provided a solid foundation for the further development of offshore gas resources.

As can be seen due to $1995-2005$ dry gas production highly increased from 29 billion to 86 billion cubic meters. At the same time as the gas production companies in Troll, Sleipner and Åsgard fields were engaged in long-term contracts. These fields are the main ones, with the addition of small volumes of associated gas from fields in the North and Norwegian Seas.

In 2007, Equinor ASA was formed as a result of the merger of Statoil with the NorskHydro oil and gas division. Equinor ASA is currently a multinational energy company with headquarters in Stavanger and a 67\% state share. Major international concerns such as ExxonMobil, ConocoPhillips, Total, Shell, Eni and others in partnership with Equinor ASA are participating in the development of Norwegian fields.

Norway sells $95 \%$ of its natural gas through pipelines and only $5 \%$ is sold as liquefied natural gas. Although already in 2007 the first natural gas liquefaction plant was built on the island of Melkoya, which today is one of the largest LNG export terminals in Europe.

As can be seen from the diagram above, in 2007, natural gas production amounted to only 90 billion cubic meters. Since 2012, net gas production has accounted for about $50 \%$ of total offshore oil production. But it was precisely during the period of lowering oil prices, in 2015-2017, that the government drew attention to the developing market for gas, emphasizing the importance of gas export. While the government does not divide net cash flows between oil and gas. 


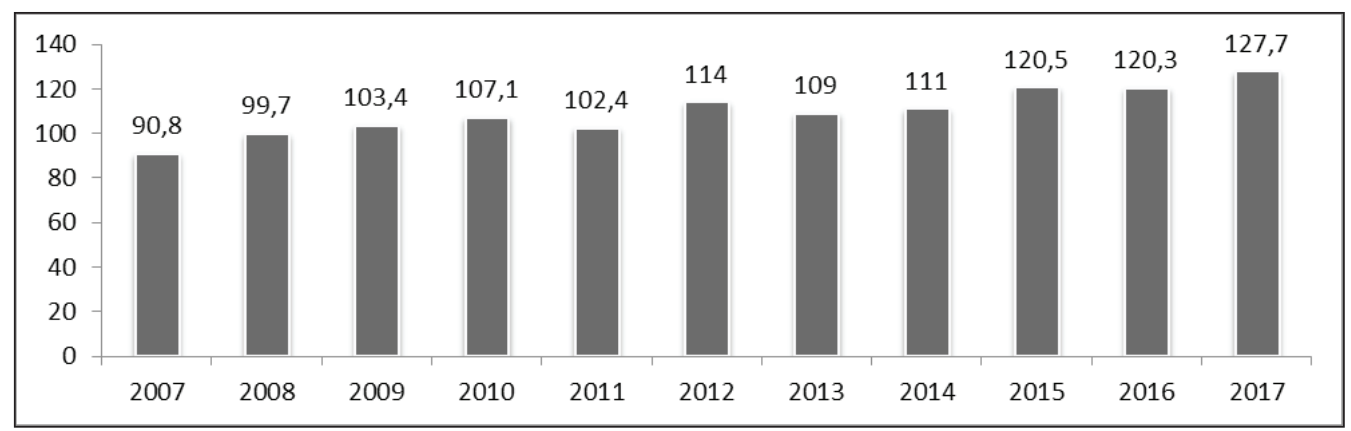

Picture 1 - Natural gas production in Norway 2007-2017 (billion cubic meters)

Note - Compiled by the author according to: https://www.ceicdata.com/en/indicator/norway/natural-gasproduction-opec-marketed-production.

In 2015-2017 the percentage of gas export revenue has been raised from $20 \%$ to $50 \%$, and it was been in spite of the great run of oil production. It is justified to conclude that lower volatility of gasrelated revenues may provide some advantages when it comes to forecasting the state budget.

The realization of set prices in energy equivalent is $50-70 \%$ of the cost of crude oil, but the cost of production, including the cost of transportation through the pipeline, is also usually lower.

Therefore, companies began offshore production from oil. And they produced gas for later sale. To conserve gas resources to enhance oil recovery and produce gas for sale at later stages of the field's operation.

Thus, the goal of maximizing the economic value of the combined oil and gas resource base is more likely to be achieved in the long term.

All licensees on the Norwegian continental shelf are responsible for the sale of their own gas. In the NCS, there are about 40 shared gas producers, each of which has the right, at its discretion, to determine how, where and to whom it sells its products.

About thirty of these manufacturers are registered shippers in the gas processing and pipeline transportation system, which gives direct access to the traded central markets.

However, in volume terms, gas marketing is largely concentrated in Statoil, which from 2010 to 2017 accounted for $70-85$ billion cubic meters per year, or $70-80 \%$ of the total pipeline gas sales from the shelf.

Statoil is the operator of the Troll and Asgardfields; Ormen Lange is managed by Shell company.

Petoro is not a licensing operator, and all of its oil and gas is sold to Statoil in accordance with the "marketing instruction" adopted by the government in 2001, which gives Statoil a high degree of marketing discretion, but also controls it by Petoro.

Statoil did not disclose the details of its derivative contracts for sale, but since 2011 the company has provided a limited summary of its annual supply obligations for the next four years arising from existing long-term contracts. These obligations are met through the supply of gas from a joint portfolio of gas resources owned by Statoil and SDFI.

In 2017, Statoil also reported that more than half of gas sales ( $>35-40$ billion cubic meters) were carried out under long-term contracts with "take or pay" exception. Most likely, a significant part of Statoil's sales (possibly 10-15 billion cubic meters per year) is currently carried out under short-term bilateral contracts for a period of one or two years, signed closer to the beginning of the delivery period.

According to table 2 (p. 253), it can be seen that over the study period, there is an increase in the volume of natural gas exports by $43 \%$ in 2017 compared with 2008 .

It is important to note that some of the income is deferred. These are state contributions to the state pension fund or the Oil Fund, the world's largest sovereign wealth fund, currently amounting to $\$ 1$ trillion. 
Table 2 - The growth rate of natural gas exports in Norway, for 2008-2017, as a percentage terms

\begin{tabular}{|l|c|c|}
\hline \multicolumn{1}{|c|}{ Year } & Export cubic meters & $\%$ \\
\hline 2008 & 85135.000 & $100,00 \%$ \\
\hline 2009 & 93052.000 & $109,30 \%$ \\
\hline 2010 & 99136.000 & $116,45 \%$ \\
\hline 2011 & 100544.000 & $118,10 \%$ \\
\hline 2012 & 111867.000 & $131,40 \%$ \\
\hline 2013 & 106596.000 & $125,21 \%$ \\
\hline 2014 & 106759.000 & $125,40 \%$ \\
\hline 2015 & 114200.000 & $134,14 \%$ \\
\hline 2016 & 114373.000 & $134,34 \%$ \\
\hline 2017 & 122485.000 & $143,87 \%$ \\
\hline $\begin{array}{l}\text { Note }- \text { Source: } \text { compiled by the authors according to the statistics: } \\
\text { https://www.ceicdata.com/en/indicator/norway/natural-gas-exports. }\end{array}$ \\
\hline
\end{tabular}

Since 2016, there have been observed the recovery in rising gas demand, stability and pliability in Northern Europe and the new investments in NCS gas projects. All that events show that the Norwegian gas production industry will be stable and confidence due to 2023 .

However, in recent years, the Norwegian oil and gas industry has faced an acute domestic political problem from proponents of tightening restrictions on offshore hydrocarbon activities for local environmental reasons and from proponents of climate change seeking to curb further offshore development.

In January 2018, there were issued the new coalition agreement, which involve current and controversial conditions in political issues for offshore operations. Major parties continue to support further offshore exploration and the oil and gas industry, but the leading parliamentary party does not allow further expansion of open sites.

The environmental problem is acute for European gas exporters, an example is the situation in the Netherlands.

At the end of 2017, the share of production in the Netherlands was more than 43 billion cubic meters. However, back in 2013 and earlier, this indicator was at around $85 \mathrm{bcm}$ in a year. The country was a major producer and exporter of natural gas in Europe. When in the post-war years and in a later period, exploration works of natural resources began, then in the course of geological studies it was found that carbonaceous coal fields were the main rocks of the Netherlands.

For the first time in 1948, gas was discovered in eastern Holland near the Coevorden village. The developer of the field was the Dutch company NederlandseAardolieMaatschappij BV (NAM), and in 1951 gas production began from this field.

A few years later, namely in 1959, the Groningen gas field was discovered in the country, the developer of which is also NAM. This is one of the largest gas fields in the world.

Initial reserves were $1960 \mathrm{bn} . \mathrm{m}^{3}$. The first production from this field was made in 1963. Since the discovery of this field, natural gas production has become one of the most important sectors in the country's economy [6]. Natural gas has become the main used energy resource not only in the Netherlands, but also for the neighboring countries of Germany, Belgium and France.

In the following years, gas fields were explored and discovered not only on land, but also on the sea shelf.

Table 3 (p. 254) below shows natural gas fields located in the Kingdom of the Netherlands. They are arranged in chronological order and with an indication of the developer.

As can be seen from table 3, in addition to the largest Groningen field, there are more than 80 small open fields, some of them mixed, oil and gas fields.

Natural gas produced at the Groningen gas field qualifies as L-gas, which refers to low-calorie gas. The qualification of natural gas, both low-calorie and high-calorie, depends on the Wobbe index of the gas. The Wobbe index indicates the thermal value of gas (Klimstra, 1986). A gas with a low calorific value contains a higher percentage of nitrogen and a lower percentage of methane than highcalorie gas, resulting in a lower Wobbe index. Therefore, the amount of thermal energy stored in a unit of low-calorie gas is lower than in the same unit of high-calorie gas. 
Table 3 - Natural Gas List of the Kingdom of Netherlands

\begin{tabular}{|c|c|c|c|c|}
\hline Name & $\begin{array}{c}\text { Production } \\
\text { start }\end{array}$ & Developer & Type & Notes \\
\hline 1. Groningen Gas Field & 1963 & NAM & Gas & $\begin{array}{l}\text { Discovered in } 1959 \text {. } \\
\text { Maximum production per day }-350 \text { bn cub m. }\end{array}$ \\
\hline 2. F4,FA gas Fields & 2009 & Centrica & Gas & Discoveredin 1971 \\
\hline 3. F4B,K5A Gas Fields & 1994 & Total & Gas & Discoveredin 1974. \\
\hline $\begin{array}{l}\text { 4. Netherlands Joint } \\
\text { Development Area Gas } \\
\text { Fields }\end{array}$ & 1975 & NAM & Gas & $\begin{array}{l}\text { Discovered in } 1975 . \\
\text { Includes more than } 50 \text { fields, } 28 \text { of them are } \\
\text { involved. }\end{array}$ \\
\hline 5. L04A Gas Fields & 1981 & Total & Gas & \\
\hline 6. De Ruyter Oil Field & 2006 & Dana Petr. & Oil/gas & Discovered in 1996. \\
\hline $\begin{array}{l}\text { 7. A and B Blocks Gas } \\
\text { Fields Development }\end{array}$ & 2008 & Chevron & Oil/gas & $\begin{array}{l}\text { There are } 2 \text { licenses for geological exploration; } \\
5 \text { production licenses }\end{array}$ \\
\hline $\begin{array}{l}\text { 8. Medway Oil\&Gas Fields } \\
\text { Development }\end{array}$ & 2012 & Dana Petr. & Oil/gas & $\begin{array}{l}\text { It was received the permission in 2010to } \\
\text { conduct development. }\end{array}$ \\
\hline
\end{tabular}

The Groningen field has a higher nitrogen content (14.2\%) compared to other European gas sources such as Russian or Norwegian gas (about 2\%) [6]. Thus, L-gas must be further processed before being delivered to the final consumer.

The complexity of gas production is reflected in the so-called marginal production costs. If the price to be received for natural gas is lower than these marginal-extraction costs, production will be unprofitable (or the producer will not produce at all). The marginal cost of the Groningen field is among the lowest in Europe. In addition, the level of production in Groningen is not regulated by time. This makes it possible to change the output signal level in accordance with market conditions. In other words, it is possible to increase production when demand/price is high, and to reduce production if demand/price falls.

The Groningenstalfield is mainly used in time of high demand. Thus, gas from this field was supplied to North-Western Europe, which ensured maximum income. Revenues from this huge reservoir of natural resources contributed greatly to the economic welfare of the Netherlands in the second half of the 20th century. In the 1980s, the share of gas revenues in total government revenue peaked at $15 \%$, but currently this contribution is gradually decreasing to about $2 \%$.

To develop the Groningen field, very large investments were required, which required state support in the construction of infrastructure for gas production and transportation. The state needed to return the invested funds, in connection with this, a new type of "take-or-pay" contract was invented, and the price of gas was linked to the price of oil. These were long-term multi-year contracts for the purchase of a certain amount of gas. The gas price in these contracts was reviewed quarterly, and if the buyer did not buy all the gas, then penalties were applied to him. Thus, the state ensured the stability of gas sales and the return on invested money.

Thanks to discovery of the Groningen field and its development, the natural gas market of Netherlands began to develop rapidly. However, during the years of the discovery of the Groningen gas field, the Netherlands government's policy was aimed at ensuring gas supply for 25 years and at the quickest depletion of the Groningen field, since it was believed that nuclear energy would be the thing of the future [4].

However, over time, the state's energy policy has changed, the oil crisis has shown the strategic importance of natural resources. This caused the changes in energy policy. The Groningen field has become a strategic reserve that must be preserved. Therefore, in 1974, the concept of Kleineveldenbeleid was introduced, which is the technology of production in small fields. Thus, the current developer (operator) of the Dutch state-owned company Gasunie committed to buy gas from small fields instead of Groningen. (Gasunie was transformed into GasTerra in 2017).

Such a policy has led to an increase in profitability from small fields. This made it possible to reduce production growth at the Groningen field and reduce the rate of depletion of this field. Until the beginning of 2000, the maximum allowable natural gas production of all gas fields in the Netherlands 
should not exceed 80 billion cubic meters. At the Groningen field, the maximum allowable production was defined as the difference between the total volume of 80 billion cubic meters and the actual production of smaller fields.

However, as practice has shown, the depletion of smaller fields occurs rather quickly, so since 2006 a long-term marginal production volume from the Groningen field has been set. So the maximum volume of natural gas produced was set at 425 billion cubic meters, with no annual limit. This means that in the period from 2006 to 2015, the total gas production should not exceed the limit of 425 billion cubic meters, and the size of the annual production remains at the discretion of the developer (operator) of the field.

Despite the measures taken, the situation with the Groningen field has worsened due to seismic activity that is not typical for this region. After careful research, the relationship between gas production and earthquakes was established. And after the 2012 earthquake near Haisinge, the Dutch government revised production restrictions [3]. A new restriction was introduced - natural gas production should not exceed a certain annual limit. In 2015, an annual limit of 27 billion cubic meters was introduced. In 2016, the permitted volume was 24 billion cubic meters, in $2017-21.6$ billion cubic meters, in 2018 the permitted production volume was 21 billion cubic meters, in 2019 the limit was set in the amount of 19 billion cubic meters. Thus, by 2022, production should be reduced to 12 billion cubic meters.

Earlier, the government planned to shut down completely and stop production from the Groningen field by 2030. However, a strong earthquake in January 2018 forced the government to reconsider plans to close the Groningen field and set a new date for the cessation of natural gas production by mid-2022.

The country's economy has become very dependent on gas production. This effect is called the "Dutch disease" [5]. As a result, the Netherlands, once thmee largest natural gas producer in the European Community and the main center for gas trade and transportation in Europe, became a net importer of gas in 2018.

Table 4 - The growth rate of natural gas exports in Netherlands, for 2008-2017, as a percentage terms

\begin{tabular}{|l|c|c|}
\hline \multicolumn{1}{|c|}{ Year } & Export cubic meters & $\%$ \\
\hline 2008 & 60088000 & $100,00 \%$ \\
\hline 2009 & 55593000 & $92,52 \%$ \\
\hline 2010 & 57751000 & $96,11 \%$ \\
\hline 2011 & 55851000 & $92,95 \%$ \\
\hline 2012 & 60411000 & $100,54 \%$ \\
\hline 2013 & 66668000 & $110,95 \%$ \\
\hline 2014 & 58661000 & $97,63 \%$ \\
\hline 2015 & 50962000 & $84,81 \%$ \\
\hline 2016 & 56597000 & $94,19 \%$ \\
\hline 2017 & 48017000 & $79,91 \%$ \\
\hline $\begin{array}{l}\text { Note - Source: compiled by the authors based } \\
\text { on statistical data: https://www.ceicdata.com/en/ } \\
\text { indicator/netherlands/natural-gas-exports. }\end{array}$ \\
\hline
\end{tabular}

According to table 4 it can be seen that during the study period there is a decrease in the volume of natural gas exports.

Until 2002, various legal regimes were applied to regulate relations in the natural gas market in the Netherlands, depending on the location of the field. One regime for onshore is territories, including territorial waters up to the border of 3 miles; and for offshore (offshore) - the Dutch part of the continental shelf.

Ground mode was regulated by:

- Napoleonic Mineral Extraction Act of 1810 (Mijnwet 1810) in its original French text, the authorized translation of which is not available (vestiges of the French occupation);

- the Mining Act of 1903 (Mijnwet 1903), with amendments which were added in 1988, on which the mining regulations of 1964 are based (Mijnreglement 1964); 
- the Mineral Exploration Act of 1967 (Wetopsporingdelfstoffen 1967) with amendments which were added in 1988.

The offshore mode was regulated by:

- Acton Mineral Extraction oncontinentalshelfof Netherlands of 1965 (Mijnwetcontinentaalplat)

- Regulation on mining 1967 (Mijnreglement 1967).

In the 1990s, European energy markets were liberalized. The goal was to stimulate competition, which was supposed to lead to lower energy prices [8].

In 2002, the Mining Act was adopted (Mijnbouwwet 2002). This law included the regulation of mining in both offshore and onshore.

According to this legislation, the Dutch state is the owner of all natural resources and minerals located at a depth of 100 meters. According to Mijnbouwwet 2002, the Dutch government can transfer production under agreement on the cession of rights. On the basis of this agreement, the concessionaire (to whom the rights were assigned) has a monopoly on resources and minerals and their income (Article 143.2 of Mijnbouwwet). Under normal circumstances, the concession owner can choose his production plan on his own.

The Dutch state is only allowed to intervene in special cases. These conditions relate to changes in insights for the planned use or management of minerals; security measures and property damage prevention. The concessionaire is also required to take and observe precautions so that development work does not cause accidents.

However, frequent earthquakes entailed political intervention, in the form of measures to reduce and, ultimately, stop gas production from Groningen. Thus, the implementation of an energy transition in which fossil energy is replaced by renewable energy. Additionally, the Dutch government is taking the necessary measures to reduce gas consumption by decrease of gas use in the residential sector and expanding central heat supply systems.

\title{
LIST OF LITERATURE
}

1 Haitun A.D. New realities of the European market // Modern Europe. 2016. № 1. P. 105.

2 BP Statistical Review of World Energy. [Electr. resource]. - 2019. - URL: https://www.bp.com/content/ dam/bp/business-sites/en/global/corporate/pdfs/energy-economics/statistical-review/bp-stats-review-2019-full-report. pdf (accessed: 25.03. 2020).

3 Global Infrastructure Investments Opportunities. CMS Infrastructure, Index. [Electr. resource]. - 2017. URL: http://www.cms.law.en (accessed: 25.03.2020).

4 The Global Competitiveness Report 2017-2018 // World Economic Forum. Geneva, 2017. P. 9. - Forum materials.

5 WTO Secretariat, Press Release // PRESS/820. - Geneva, 2018. P. 19. Press Release.

6 WTO and UNCTAD Secretariats Press Release // PRESS/820. - Geneva, 2018. P. 21. Press Release.

7 Eurogas Response to DG ENERGY Consultation on an EU strategy for liquefied natural gas and gas storage. [Electr. resours]. - URL: http://www.eurogas.org/uploads/media/15CR353 (accessed: 25.03. 2020).

8 Norwegian Gas Exports: Assessment of Resources and Supply to 2035. [Electr. resours]. - URL: https://www.oxfordenergy.org/wpcms/wpcontent /uploads/2018/03/Norwegian-Gas-Exports-Assessment-ofResources-and-Supply-to-2035-NG-127.pdf (accessed: 25.03. 2020).

3.А. ИМАНГОЖИНА, ${ }^{1}$ экономика ғылымдарының магистрі, докторант. «Қаржы академиясы» АҚ

\section{НОРВЕГИЯ МЕН НИДЕРЛАНДЫДАҒЫ ГАЗ САЛАСЫНЫН ДАМУ ТАРИХЫ МЕН ЕРЕКШЕЛІКТЕРІ}

\begin{abstract}
Андатпа
Табиғи газ қазіргі әлемнің энергетикалық жүйесінде жетекші орындардың бірін алады. Декарбонизация саясатына байланысты көмірді тұтынудан алшақтап, ішкі қажеттіліктерге экологиялық таза шикізатты қолданатын елдер саны артып келеді. Мақалада Еуропадағы табиғи газ кен орындарының екі көшбасшысы: Норвегия мен Нидерланды туралы мәліметтерге шолу мен талдау жасалған. Газ нарығының даму тарихына
\end{abstract}


және оның Еуропалық қоғамдастықта және әлемде осы саланың қалыптасуына әсеріне ерекше назар аударылады. Тролль мен Гронингеннің ең ірі кен орындары, қазіргі уақытта белгілі кен орындары Экофикс, Фригг, Дроген, Озберг, ОрменЛанг, F4B, K5A, F4, FA және басқалары сияқты атағы шыға қоймаған шағын кен орындары қарастырылады. Норвегиялық континентальды шельфте мұнай-газ ресурстарының дамуы көмірсутектердің алғашқы коммерциялық өндірісі 1971 ж. басталғаннан бері әр түрлі даму жолдарынан өтті. Норвегиялық континенттік шельфтегі барлық лицензия иелері өз газдарын сатуға жауапты. Керісінше, Гронинген кен орнын игеру үшін өте үлкен инвестицияларды қажет еткен Нидерланды жаңа типтегі «takeopray» - «қабылдау немесе төлеу» келісімшартын жасады, ал газ бағасы мемлекеттік инвестицияның үлкен көлемін қайтару үшін мұнай бағасына байланысты болды. Мақалада аталған елдерде саланы дамыту бойынша кейбір нәтижелер шығарылды.

Тірек сөздер: еуропалық газ нарығы, табиғи газ, газ экспорты, мұнай ресурстары, инвестициялар, энергия жүйесі, кен орындары.

3.А. ИМАНГОЖИНА, ${ }^{1}$ магистр экономических наук, докторант. АО «Финансовая академия» 1

\title{
ИСТОРИЯ РАЗВИТИЯ И ОСОБЕННОСТИ ГАЗОВОЙ ОТРАСЛИ В НОРВЕГИИ И НИДЕРЛАНДАХ
}

\begin{abstract}
Аннотация
Природный газ занимает одно из ведущих мест в энергосистеме современного мира. Все больше стран используют экологически чистое сырье для внутренних нужд, отходя от потребления угля в связи с политикой декарбонизации. Статья представляет обзор и анализ данных по двум лидерам по залежам природного газа в Европе: Норвегии и Нидерландам. Особое внимание уделено истории развития газового рынка королевств и его влиянию на становление данной отрасли в Европейском сообществе и в мире. Рассматриваются как наиболее крупные месторождения Тролль и Гронинген, так и малоизвестные небольшие месторождения, открытые на данный момент, такие, как Экофикс, Фригг, Дроген, Озберг, ОрменЛанг, F4B, K5A, F4, FA и другие. Разработка нефтяных ресурсов и газовых ресурсов на Норвежском континентальном шельфе шла разными путями с момента начала первой промышленной добычи углеводородов в 1971 г. Все лицензиаты на Норвежском континентальном шельфе несут ответственность за продажу собственного газа. В противовес Нидерланды, которым для разработки Гронингенского месторождения были необходимы очень большие вложения, разработали новый тип контракта «take or pay» - «бери или плати», а цена газа была привязана к цене на нефть для возврата большого количества государственных инвестиций. В статье подведены некоторые итоги по развитию отрасли в данных странах.
\end{abstract}

Ключевые слова: европейский рынок газа, природный газ, экспорт газа, нефтяные ресурсы, инвестиции, энергосистема, месторождения. 